\title{
Meat Production through Evaluation of Stallion Prospects for Simmental and Simbrah Cattle
}

\author{
Nelson Manzanares-Miranda ${ }^{1}$, Horacio Villalón-Mendoza ${ }^{2}$, Gustavo Moreno-Degollado ${ }^{1}$ and Jorge Ramsy Kawas ${ }^{3}$ \\ 1. Centro de Investigacion y Produccion Agropecuaria, Universidad Autónoma de Nuevo León (UANL), Linares, N.L. 67700, Mexico \\ 2. Agroforestry Department, Facultad de Ciencias Forestales, Universidad Autónoma de Nuevo León (UANL), Linares, N.L. 67700, \\ Mexico
}

3. Facultad de Agronomía, Universidad Autónoma de Nuevo León (UANL), Escobedo, N.L. 66050, México

\begin{abstract}
In the world, many research has been made to increase the quality and quantity of food production, and also to seek increase of accessibility of consumption for the population, especially in low economic income communities, where the consumption of protein may be very important for public health and sustainable development. The main objective of this study was to generate knowledge to increase food safety in the production of meat through the assessment of cattle that are prospect to be stallions of the Simmental and Simbrah breeds. This took place in Linares, Nuevo Leon, Mexico. The period of time for the test to get accurate data regarding food consumption in this study was $70 \mathrm{~d}$. The Simmental breed surpasses the Simbrah breed, with respect to increase in daily weight and increase in final weight $(P \leq 0.05)$. If Northeast México is looking to enhance food safety through a higher increase in final weight, then it should consider the Simmental breed as the most appropriate.
\end{abstract}

Key words: Simmental, Simbrah, stallions, food security.

\section{Introduction}

Mexico is a country that is concerned to increase the quality and quantity of food production and rely less on imports that generate high prices, causing a decrease in consumption accessibility of its population, especially in low-income communities, where the consumption of protein may be very important for public health and sustainable development. Mexico is a country with Simbrah and Simmental breeds registered as purebred Fleckvieh, a true dual-purpose breed which are highly efficient in dairy production without losing the genetic capacity of calves' efficiently producing meat in grazing without additives, special for commercial breeding [1].

For Mexico, agricultural and forestry production units are the main land use in the country, covering an area of 112.3 million ha, which represents $57.3 \%$ of the national territory, according to information from

Corresponding author: Horacio Villalon-Mendoza, Ph.D., research field: agroforestry systems. the eighth census of agricultural, livestock and forest $[2,3]$.

On the other side, according to the data of the service of information and statistics of agric-food and fisheries, Mexico has a great diversity of livestock genetic resources, with a total of 45 cattle breeds, of which 26 are European breed, seven are Zebu and 12 are crossbreeding between European and Zebu breeds [4].

The State of Nuevo Leon, Mexico, has a livestock area reaching up to a little more than 5.5 million ha, $86 \%$ of the state area, of which $90 \%$ are rangeland and the remaining $10 \%$ are prairies. The livestock inventory in the State of Nuevo Leon reaches up to 386,474 cattle [3].

The State of Nuevo León has been internationally recognized for the beef quality production. Additionally, in Nuevo Leon, the consumption per capita, said meat, is $37 \mathrm{~kg} / \mathrm{year}$, according to the Corporation for the Agricultural Development of Nuevo Leon [5], and it is the highest meat consumption in the country, which also compares 
favorably with the national average of $21 \mathrm{~kg} / \mathrm{year}$ [3].

According to the Corporation for the Agricultural Development of Nuevo Leon, Mexico [5], the predominant production system is extensive rangeland. In terms of induced grassland, there are approximately 540,000 ha induced temporary meadows, with buffel grass predominating (Cenchrus ciliaris). There is close to 20,000 ha of prairie with irrigation systems, with African star and Bermuda crossbred grass, in addition to about 150,000 ha of fodder, such as sorghum, corn, oats, grass, alfalfa crops, among others with little proportion [3].

In several currently used practices for genetic improvement, the evaluation of stallion prospects has the advantage of assessing and identifying the best stallions at an early age, allowing the improvement of growth and carcass traits for future generations. This can be accomplished through selection for characteristics that can be measured in vivo using ultrasound technique, and that are good indicators of the carcass quality, intramuscular fat (marble index), rib eye area (REA) and fat thickness (FAT). These tests are of major importance, as meat products, especially those from bovine cattle, are currently facing great challenges and opportunities, among which we can emphasize the urgent need to increase competitiveness in the global competition that Mexico is facing [3].

The technology of ultrasound to predict the composition and quality of the carcass in vivo is an important tool for the evaluation and improvement of the carcass merit for beef cattle, without resorting to direct measurements in the carcass of related animals, which is expensive and takes time for the genetic evaluation.

The origin of the Simmental breed is in the Simme Valley located in the Berner Oberland, Switzerland. Simmental name derives from its original location. In the German language, the word "Thal" or "Tal" means "Valley". Simmental literally means valley of the Simme. This valley is located where the River Simme flows in the Middle and West of Switzerland, where the climate is cold and there is Alpine and sub-alpine vegetation that offers excellent prairie [3].

Besides evaluating the different production characteristics of economic importance for Simmental and Simbrah breeds under a proper uniform environment, this study sought to show the manifested differences due to the genetic quality of each individual. The main objective of this study was to generate knowledge to increase food safety in the meat production through the assessment of cattle that are prospects to be stallions of the Simmental and Simbrah breeds.

\section{Materials and Methods}

The present research used the behavioral evaluation tests of prospects to stallions, which have been proven to be one more tool to select sires whose production characteristics are superior to his contemporaries. The Simmental-Simbrah Mexican Breeders Association invited all partners to participate by sending their cattle to the evaluation test of prospects to stallions, which took place in the facilities of the Center of Research and Agricultural Production at the Universidad Autonoma of Nuevo Leon, located on national road of Linares-Ciudad Victoria $145 \mathrm{~km}$ in the municipality of Linares, Nuevo Leon, Mexico.

The process of the research was carried out as following $[3,6,7]$.

\subsection{Reception of the Stallions}

Sires were received on the premises of the Centre of Research and Production on January 4 through January 13, 2010.

Upon arrival a visual, individual and group evaluation were performed. The animals were distributed in uniform batches by their live weight. The health management of gastro-enteric worming and ectoparasites was conducted, and then vaccinated against infectious bovine rhinotracheitis (IBR), bovine respiratory syncytial virus (BRSV), parainfluenza 
(PI3), bovine viral diarrhea (BVD), CattleMaster 4 Pfizer ${ }^{\circledR}$ and clostridial 7 way Ultrabac 7 Pfizer ${ }^{\circledR}$. Likewise, vitamins $\mathrm{A}, \mathrm{D}$ and $\mathrm{E}$ were applied. The adaptation period was $19 \mathrm{~d}$ (from January 4 to January $22,2010)$. They were provided the balanced feed with $16 \%$ crude protein, plus ad libitum forage.

The start date for the evaluation took place at 8:00 am of January 23, 2010, taking first the initial weight of each young bull. Before weighing, stallions were put on a food and water diet for $12 \mathrm{~h}$, scrotal circumference and hip height were also measured. According to the weight results, food amount was adjusted to each pen to $3 \%$ of the present live weight.

The weighing was performed every $28 \mathrm{~d}$ on the following dates: the 1st weighing on January 23, 2010; the 2nd weighing on February 20, 2010; the 3rd weighing on March 20, 2010; the 4th weighing on April 17, 2010; the 5th weighing on May 14, 2010.

Characteristics or variables that were measured to evaluate the prospects to stallions included:

(1) Daily gain for the period (DGP) calculated as Eq. (1):

$$
\begin{gathered}
\mathrm{DGP}=(\text { final weight }- \text { initial weight }) \\
\text { /the days of the test }
\end{gathered}
$$

(2) Daily gain by age (DGA). Weight gain per day of age was calculated as Eq. (2):

$$
\mathrm{GDE}=(\text { final weight }- \text { birth weight })
$$

/age in days at the end of the test

(3) Weight adjusted to $365 \mathrm{~d}$. Adjusted yearling weight is a useful measure, because it combines the weaning weight adjusted to the post-weaning growth of the animal. Post-weaning growth is mainly determined by the potential of the individual, as Eq. (3):

$$
\begin{gathered}
\text { Weight adjusted to } 365 \mathrm{~d}= \\
\text { (year weight }- \text { weight at weaning }) \div \\
(365 \mathrm{~d}-\text { days at weaning }) \times \\
(160+\text { adjusted weight } \times 205 \mathrm{~d})
\end{gathered}
$$

(4) The tenderloin area. The measurement of rib eye area carried out with ultrasound equipment brand Aloka $500 \mathrm{v}$, with a linear transducer of $17 \mathrm{~cm}$ and 3.5 MHz (software company The National CUP Lab. \&
Technology Center, Ames, IA, USA).

(5) Percentage of fat intramuscular.

(6) Dorsal fat.

(7) Genetic markers (softness of the meat and marbling).

(8) Body size. The formula used to calculate the body height for males was as Eq. (4):

$$
\begin{gathered}
\text { Frame score }=-11.548+(0.4878 \times \mathrm{Ht})- \\
(0.0289 \times \text { age })+\left(0.00001947 \times \mathrm{age}^{2}\right)+ \\
(0.0000334 \times \mathrm{Ht} \times \text { age })
\end{gathered}
$$

where, age $=$ days of age and $\mathrm{Ht}=$ hip height in inch.

(9) Scrotal circumference (SC). The measurement was taken with a tape measure in the wide part of the scrotal pouch, the formula adjustment at $365 \mathrm{~d}$ is as Eq. (5):

$$
\begin{gathered}
\text { Adjusted } 365 \mathrm{~d} \mathrm{SC}=\text { actual } \mathrm{SC}+ \\
{[(365 \mathrm{~d}-\text { days of age }) \times \text { age adjusted factor }]}
\end{gathered}
$$

It is noteworthy that scrotal circumference is an indicator of the bulls fertility and will have a positive effect on the reproductive behavior of the daughters, such as early puberty. This is also considerable evidence that the measurement of the scrotal circumference in a 1-2 years old bull has a moderate to high heritability [1].

\subsection{Cattle Nutrition}

The food ration was provided on the basis of a balanced diet containing $60 \%-70 \%$ of available nutrients, in general total 2.2-2.6 Mcal/kg dry matter and $16 \%$ crude protein. The ingredients for this ration were sorghum grain, soybeans, ground bale of forage, molasses and vitamins and minerals premix.

\subsection{Climate Conditions While the Investigation Carried Out}

The municipality of Linares, Nuevo Leon, Mexico, has a semi-hot, sub-humid climate, registering an average annual temperature $21.4{ }^{\circ} \mathrm{C}$ and extreme temperatures of $42{ }^{\circ} \mathrm{C}$ in summer and $-2{ }^{\circ} \mathrm{C}$ in winter. The increased storm rainfall is typically recorded in the month of September, which oscillates between 170 
Table 1 Rainfall and temperature presented during the research, from January to May 2010.

\begin{tabular}{llllll}
\hline Month & $\begin{array}{l}\text { Rainfall } \\
(\mathrm{mm})\end{array}$ & $\begin{array}{l}\text { Accumulated rainfall } \\
(\mathrm{mm})\end{array}$ & \multicolumn{3}{c}{ Temperature $\left({ }^{\circ} \mathrm{C}\right)$} \\
\cline { 4 - 6 } & 30.2 & 30.2 & Max. & Min. & Average \\
\hline January & 35.5 & 65.7 & 25.0 & 2.0 & 13.5 \\
February & 4.0 & 69.7 & 28.0 & 2.0 & 15.0 \\
March & 190.5 & 260.2 & 34.0 & 5.0 & 19.5 \\
April & 7.5 & 267.7 & 35.0 & 10.0 & 22.5 \\
May & & 36.0 & 14.5 & 25.3 \\
\hline
\end{tabular}

Source: Wether Stations of Centro de Investigación y Producción Agropecuaria and Facultad de Ciencias Forestales, UANL.

$\mathrm{mm}$ and $180 \mathrm{~mm}$, and the minimum is in the months of January and December, between $15 \mathrm{~mm}$ and $20 \mathrm{~mm}$. It is worth mentioning that the prospects to stallions were evaluated under weather conditions presented in Table 1, which should be taken into consideration in the subsequent performance of the prospect.

\section{Results}

The statistical analysis showed a high statistical difference between the total gains by both of the breeds tested, and also showed highly significant statistical difference in the values of average daily gain for both breeds $(P=0.007)$. No statistical difference with regard to the average gain of the two breeds was found.

The period of time for the test to get accurate data regarding the consumption of food in this study was $70 \mathrm{~d}$. The differences between breeds in response to the components of variance to increase the duration of the tests are less. There might be a slight trend occurring in the Simmental bulls that requires a longer duration in tests in comparison with other breeds due to some traits, but these differences are not consistent.

The increase in the final weight for Simmental breed over Simbrah is significantly higher $(P=0.006)$, so it can be said that Simmental breed shows a better gain value at the end of the test, even though management costs were the same for both breeds in the conditions under which the test was performed.

\section{Discussion}

The foregoing result is supported by the findings of
Kemp [8] and Brown et al. [9]. Some ones recommend a duration period for growth rate measurement in different literatures including $70 \mathrm{~d}$ [6], $84 \mathrm{~d}$ [7] and 112 $\mathrm{d}[8,9]$. The studies recommended $112 \mathrm{~d}$ generally on the basis of phenotypic correlations with a 140-day test, and while do not consider problems with auto correlation data, those recommended a shorter tests (70-84 d) based on variation of components.

With regard to the daily gain for each breed, the same behavior is shown to be greater in Simmental sires, even though Simbrah breed is a crossbred between a Simmental and a Zebu, and this was done with the objective to better tolerate extreme environmental conditions that are presented in Northeast Mexico, where the study was conducted.

The genetic contribution of Zebu breed, does not even gets equal, nor higher than that in Simmental breed in terms of daily weight increase [3].

The above can be compared to the findings of Renand et al. [10], where Charolais and Limousin cattle were used to estimate the genetic correlation that exists in the sires evaluations of the central station, and bulls were subsequently used to test and study its progeny, finding that when selecting by growth rate and residual feed intake, there was a significant increase in the progeny capacity of muscle growth in response to the selection of Charolais cattle [3].

Regarding the daily gain, it is known that in the State of Sonora, Mexico, an assessment of prospects to stallions in feedlot was conducted with a duration of $140 \mathrm{~d}$, providing them with a complete diet, and the breeds tested were Charolais, Indobrasil and 
Simmental having a daily gain of 1.488, 1.183 and $1.457 \mathrm{~g}$, respectively $[11,3]$; whereas in the present study, the Simmental breed presented a daily gain superior of the order of $1.680 \mathrm{~g}$.

Hernández et al. [12] and Franklin et al. [13] mentioned that in the selection of young bulls for stallions, it should be taken in consideration some important characteristics, such as the weight, the daily gain and the scrotal circumference, as well as other phenotypic characteristics, in order to achieve an efficient selection and obtain a major genetic progress. Therefore, among the most important characteristics are mainly the daily weight gain, height, scrotal circumference, characteristics of body composition measured with ultrasound and the fertility test $[3,14]$.

Johnson et al. [15] mentioned in a study that the purebred bulls as Hereford and Simmental $(n=120)$ were evaluated for their reproductive parameters. Four diets, used all the same in composition, with the exception of dietary fiber, were given during the test of growth behavior, and the diet had no direct effect in any of the reproductive variables examined.

Of the 117 bulls evaluated for good reproduction health, $75 \%$ were classified as satisfactory potential breeders, $24 \%$ as "questionable" potential breeder and $1 \%$ as unsatisfactory potential breeder. In the present study, no statistical significant differences were found between the two breeds with a level of $P>0.05$ in the following variables, weight adjusted to $365 \mathrm{~d}$, rib eye area, percentage of intramuscular fat, back fat, genetic markers (softness and marbling), body size and scrotal circumference $[3,16]$. The last mentioned tell us that both breeds possess these same traits, under the conditions in which the study was conducted.

In this case, as Manzanares-Miranda et al. [3] have found, if looking for an enhanced increase in final weight, then the Simmental breed should be considered as the most appropriate in Northeast México.

\section{Conclusions}

The knowledge generated through this research to increase food safety in the production of meat through the assessment of cattle that are prospects to be stallions of the Simmental and Simbrah breeds was as the following. The Simmental breed behaved better than the Simbrah $(P \leq 0.05)$, respect to daily weight increase and final weight increase. If looking for a higher increase in final weight, then the Simmental breed should be considered as the most appropriate in Northeast México. And likewise, it was noted that there were no statistically significant differences between the two breeds $(P>0.05)$ with respect to the variables of weight adjusted to $365 \mathrm{~d}$, rib eye area, intramuscular fat percentage, back fat, genetic markers (softness marbling), body size and scrotal circumference.

\section{References}

[1] Mexican Association of Simmental-Simbrah. 2014. "History of the Simmental." Online Magazine, Monterrey, Nuevo Leon, Mexico. Accesed December 15, 2015. http://www.simmentalsimbrah.com.mx/historia_simment al.html.

[2] National Institute of Statistics and Geography (INEGI). 2007. Methodological Synthesis VIII Census of Agriculture, Livestock and Forestry, 1th ed.. Aguascalientes, Mexico: INEGI, 1-3.

[3] Manzanares-Miranda, N., Villalon-Mendoza, H., and Moreno-Degollado, G. 2015. "Evaluation of Prospects Cattle Stallions of the Breed Simmental and Simmbrah." Global Journal of Animal Scientific Research 3 (1): 57-64.

[4] SAGARPA. 2002. Report on the Situation of the Animal Genetic Resources (RGP) in Mexico.

[5] Corporation for the Agricultural Development of Nuevo Leon (CDA). 2008. Diagnosis of the Agricultural Sector and Aquaculture of the State of Nuevo Leon.

[6] Archer, J. A., and Bergh, L. 2000. "Duration of Performance Tests for Growth Rate, Feed Intake and Feed Efficiency in Four Biological Types of Beef Cattle.” Livestock Production Science 65 (1-2): 47-55.

[7] Swiger, L. A., and Hazel, L. N. 1961. "Optimum Length of Feeding Period in Selecting for Gain of Beef Cattle.” $J$. Animal Sci. 20: 189-94.

[8] Kemp, R. A. 1990. "Relationships among Test Length and Absolute and Relative Growth Rate in Central Bull Tests.” J. Animal Sci. 68 (3): 624-9.

[9] Brown, A. H., Chewning, J. J., Johnson, Z. B., Loe, W. C., and Brown, C. J. 1991. "Effects of 84-, 112- and 
140-day Postweaning Feedlot Performance Tests for Beef Bulls.” J. Animal Sci. 69 (2): 451-61.

[10] Renand, G., Fouilloux, M. N., and Menissier, F. 1998. "Genetic Improvement of Beef Production Traits by Performance Testing Beef Bulls in France." In Proceedings of the 6th World Congress on Genetics Applied to Livestock Production, 77-80.

[11] López, R. 1981. Summary of Progress of Research. Trustees of the Livestock Research Center of the State of Sonora, Sonora, Mexico.

[12] Hernández, C. H., Anchondo, A. G., Ramírez, A. G., Ortega, J. A. G., and Estrada, Y. A. 1995. "Evaluation of Bullocks Salers under Test of Behavior under Conditions of Irrigated Pasture." In Proceedings of the Meeting of the Mexican Association of Animal Production, 13-7.

[13] Franklin, C. L., Thayne, W. V., Wagner, W. R., Stevens, L. P., and Inskeep, E. K. 1987. "Factors Affecting Gain of Beef Bulls Consigned to a Central Test Station." Bulletin 693, Agricultural and Forestry Experiment
Station, West Virginia University, Morgantown, USA. Accessed December 15, 2015. http://agris.fao.org/ agris-search/search.do?recordID=US8921541.

[14] Rodríguez-Almeida, F. A. 1997. "Strategies for the Establishment of Programs for Genetic Evaluation of Beef Cattle." Presented at the First Forum for the Analysis of the Genetic Resources of the Bovine Cattle, Universidad Autónoma de Tamaulipas, Ciudad Victoria, Tamaulipas, Mexico.

[15] Johnson, H. W., Thompson, A. J., Kumi-Diaka, J., Wilton, W. J., and Mandell, B. I. 1995. "The Determination and Correlation of Reproductive Parameters of Performance-Tested Hereford and Simmental Bulls." Theriogenology 44 (7): 973-82.

[16] Barth, A. D. 1997. "Evaluation of Potential Breeding Soundness of the Bull." In Current Therapy in Large Animal Theriogenology, 1st ed., edited by Youngquist, R. S. Philadelphia, Ames, IA: W.B. Saunders Company, 222-36. 